\title{
ВІКОВІ ОСОБЛИВОСТІ СПРИЙМАННЯ ГЕРОЇВ ТВОРІВ В ЯКОСТІ РОЛЬОВИХ МОДЕЛЕЙ
}

\begin{abstract}
Анотація. Досліджено різнищю поглядів на рольові орієнтири з книжок, казок та серіалів дорослої та молодої аудиторії. Емпірична база представлена особисто складеними питаннями у вигляді авторського опитувальника на дослідження ставлення дорослої та молодої аудиторї до персонажів 3 книг, фрільмів, серіалів та ін. розважальних мас-медіа. Опитування проходило шляхом розповсюдження двох версій гуглформи у соціальних мережах. Питання стосувалися наступного: наявності героя в дитинстві, опитування ставлення до героїв сьогоднішньої розважальної мас-медіа, питання про їх необхідні та небажані якості, а також найкращого героя в якості рольової моделі для сьогоднішніх дітей. Дослідження проводилося на двох вікових групах: доросла група (32-55 років) та молодша (19-25 років). Виявлено, що геройство для старшої вибірки та сила духу, та неоднозначність для молодшої.
\end{abstract}

Ключові слова: читання, рольові моделі, соціалізація, особистість, мас-медіа.

Pokrovska Polina, Milutina Katerine Taras Shevchenko National University

\section{AGE FEATURES OF PERCEPTION OF HEROES OF WORKS AS ROLE MODELS}

Summary. The difference of views on the role guidelines from books, fairy tales and series of adult and young audiences is investigated. The empirical base is presented by personally composed questions in the form of the author's questionnaire on research of the relation of adult and young audience to characters from books, films, serials, etc. entertainment media. The survey was conducted by distributing two versions of the Google form on social networks. The questions concerned the following: the presence of a hero in childhood, a survey of attitudes towards the heroes of today's entertainment media, questions about their necessary and undesirable qualities, as well as the best hero as a role model for today's children. The study was conducted on two age groups: adult group (32-55 years) and junior (19-25 years). It was found that heroism for the older sample and strength of spirit, and ambiguity for the younger. the adult audience did not fully understand the complex characters such as Sam, Severus Snape, Shrek and generally less inclined to associate themselves with any characters. She values "superficial qualities" more, and young people today appreciate the complexity of character and pay attention to the person in general, to his motives, rather than behavior. The results do not show the trend described by modern authors. Questions of morality remain relevant for both young and old - as an example to follow, no one cited the antihero, as well as his subjectively questionable qualities. Image of the example to follow, although slightly different with different generations, but its general features and direction remain the same. The difference between the generations is visible in the qualities that the two samples showed for the heroes of childhood and the heroes of today (heroism for the older sample and strength of spirit, ambiguity for the younger). This may be due to a change in the direction of the media itself in who is now understood as the heroes. For the younger audience, the most positive qualities were intelligence and altruism, the qualities associated with a good attitude towards others, and the negative - those associated with their opposite pole. The adult audience is more focused on educating their own character, no longer associated with society, but with some higher values of self-development.

Keywords: reading, role models, socialization, personality, mass media.

$\Pi^{2}$ остановка проблеми. Наше століття по правді можна вважати «інформаційною епохою» $\mathrm{i}$ «століттям інформаційних технологій». Молодь 21-го століття вже більше не стільки орієнтується на батьків, як прикладів для наслідування, тому що має більш широке коло доступних ролевих моделей. А герої, яких зображує індустрія розваги зараз дуже привабливі: вони вже позбулися притаманного їм раніше ідеального і доблесного характеру, ставши більш людяними, що приваблюе підлітків своєю щирістю. Відсутність чіткого поняття кумира, його цінностей і характеру у молоді зараз і їі відмінність від нього ж кілька десятиліть тому для їх батьків, являе собою велике поле для дослідження саме через вплив часу на ці погляди, і можливість конфрліктів, які можуть теоретично виникати на цьому грунті між поколіннями.

Аналіз останніх досліджень та публікацій. За словарем АПА [9], рольова модель (від англ. role model) - це особа чи група (осіб), яка служить прикладом цілей, поглядів чи поведінки особистості, яка ототожнюе себе та намагається імітувати зразок для наслідування. Таким чином поняття можна розуміти як синонім більш звичного для нас «зразок для наслідування».

Американська дослідниця М. Прайс-Мітчелл (Marilyn Price-Mitchell, 2015), у результаті проведеного дослідження, у якому підлітки та юнаки розповідали про людей, що надихнули їх стати тими, ким вони є зараз [8], виділила 5 основних якостей рольової моделі для сьогоднішньої молоді: пристрасть і здатність надихати інших, мають чіткий набір своїх життевих цінностей, орієнтування на соціум, прийняття інших та безкорисливість у діях, здатність долати перешкоди [8]. У дослідженнях виокремлюються певні сучасні тенденції молоді. Так, С.В. Черноборовкіна у дослідженні героїв сучасних підлітків [7], дійшла висновку, що сучасна молодь формуе своє 
враження про героя через «екрану плоскість». У дослідженні було визначено, що дівчата більш схильні розуміти під героєм чарівних персонажів, а хлопці персонажів-супергероїв. Старші підлітки дівчата вже більше орієнтуються на реальних популярних людей, хлопці ж залишають собі телевізійних героїв [7].

М. Желобенко [1] пояснює вплив серіалів на людину сьогоднішнього через «кліпове мислення». Вплив через різні медіа розважального характеру діє не безпосередньо, а латентно, тому він такий дієвий. Також вплив серіалів визначається їх тривалістю, а тобто багаторазовим закріпленням. Із конкретних прикладів, розглядаючи діяльність режисера Мігеля Сабідо, стверджується, що він упевнений що серіали цілком годяться для просування соціальних цілей в маси. При тому режисер за допомогою просування серіалів в маси істотно скоротив рівень народжуваності в Мексиці [1].

У дослідженні Л.В. Оконечнікової й ін. [4], дорослі експертно оцінювали мультики, які дивилися їхні діти за кількома критеріями. В результаті дослідження встановлено, що: по-перше вікові групи батьків розрізнялися за ощінками мультфільмів, і по-друге, батьки обох груп не рекомендували найпопулярніший до перегляду у дітей 7-10 років мультсеріал, а саме «Гравіті Фолз», для цієї вікової аудиторії. Тим не менш, такі результати досить суперечливі, оскільки батьки не завжди можуть ращіонально поглянути на ту чи іншу діяльність сучасного розважального мас-медіа та правильно ощінити той чи інший мультфільм 3 точки зору його впливу на дитину.

Теряева О.А. також говорить про «героїзацію пороку» [6]. Вона відбувається через засоби масової інформації: телебачення, кіно, журнали і т.д.. Так, піднімається питання героїв, антигероїв і псевдогероїв, притому слід чітко розрізняти ці поняття, так як під псевдогероями розуміється якийсь кумир, який не маєбути прикладом для молодого покоління.

За проведеним дослідженням Н.Б. Ковальової [2], підліткам, пропонувалося вибрати персонажа, якого вони вважають героєм в різних творах медіакультури. Кількість реальних і вигаданих героїв, названих респондентами виявилася практично однаковою. 3 «героїв» підлітки найбільш виділили кіноперсонажів, на другому місці - літературні герої, на третьому - герої комп'ютерних ігор. При тому, кіногероїв в два рази більше ніж літературних персонажів. Найбільш діти поважали в них такі якості як: самодостатність, харизматичність, доброту, справедливість, щирість [2].

За дослідженням В.С. Собкіна і Е.А. Калашнікової [5], з героїв мас-медіа у підлітків найбільш представлені групи ідеалів і антиідеалів 3 літератури, менше з кіно, трохи відстають героїв екранізованих літературних творів. Характерною є важливість для підлітків ідеалів з розважальних мас-медія у зрівнянні з кількістю таких ідеалів з реального життя - із віком перших буде ставати менше, а кількість других зростатиме.

Варто також зауважити, що більшість дослідників даної області так чи інакше належать до дорослої аудиторії, й розглядаючи результати досліджень, потрібно брати до уваги цей фракт. Так наприклад, О.А. Немова і А.Ф. Бурухіна [3] хоч і піднімають важливу тему сім'ї в сучасних мультиках, але роблять це дуже однобічно. Аналізуючи радянські, російські та західні мультфільми, автори прийшли до висновку, що в останніх неправильно представляється модель сім'ї. Так, автори вихваляють радянські мультфільми і ставлять під сумнів якості, які виховують мультфільми в дітях. Також сумнівно читати, як автори наполягають на потрібності мультиків, які прищеплюють дітям любов до багатодітних сімей, а однодітні та взагалі сім'ї без дітей не сприймаються як норма [3]. Висновки таких авторів зводяться до суто консервативних поглядів на сім'ю, як і на всі відносини поза рамками «нормального». Дослідниця О.А. Теряєва [6] розглядає поняття «героїв», «псевдогероїв» та «антигероїв» через православні цінності. Це ще раз говорить про актуальність даної теми в дослідженнях молодих дослідників, яких, на жаль не так вже й багато. Тим не менш, можна зробити й інший висновок, до якого також дійшла дослідниця Л.В. Оконечнікова [4]: дорослим треба ретельно підбирати те, що будуть дивитися їх діти, щоб розвивати в них саме ті якості, які вони хочуть розвинути.

Виокремлення недостатньо розглянутої частини проблеми. Так, аналіз досліджень свідчить, що загальна більшість авторів відзначають великий вплив на молодь кіно і медіакультури, і дуже малий вплив найближчого оточення: батьків, вчителів, знайомих і т. д. Але недостатньо розглянуто динаміку рольових орієнтирів в залежності від віку респондентів.

Мета дослідження: дослідити різницю поглядів на рольові орієнтири 3 книжок, казок та серіалів дорослої та молодої аудиторії.

Виклад основного матеріалу. Емпірична база представлена особисто складеними питаннями у вигляді авторського опитувальника на дослідження ставлення дорослої та молодої аудиторії до персонажів 3 книг, фрільмів, серіалів та ін. розважальних мас-медіа. Опитування проходило шляхом розповсюдження двох версій гугл-фрорми у соціальних мережах Facebook, Viber та Telegram. Питання стосувалися наступного: наявності героя в дитинстві, опитування ставлення до героїв сьогоднішньої розважальної мас-медіа, питання про їх необхідні та небажані якості, а також найкращого героя в якості рольової моделі для сьогоднішніх дітей.

Дослідження проводилося на двох вікових групах: доросла група (32-55 років) 26 осіб та молодша (19-25 років) 32 особи.

Результати проведеного дослідження. За результатами можна сказати, що у більшості людей у дитинстві були рольові моделі, у молоді загалом більше ніж у дорослих. У всіх герої різні, наприклад, для старшої аудиторії - Робін Гуд, Добрий чарівник, піонери-герої, Штірліц, Ілля Муромець, Іляна Розоляна та ін. Ці герої зібрані 3 різних джерел. Для молодшої - Бетмен, Барон Мюнхаузен, Кінь Спіріт, Білосніжка, Істред Валь та ін. Герої групи розподілилися на персонажів мультфільмів та книг.

Для дорослої аудиторії головними якостями в їх власних рольових моделях в дитинстві загалом був ïx розум, вміння всіх перемагати та відвага. Мо- 


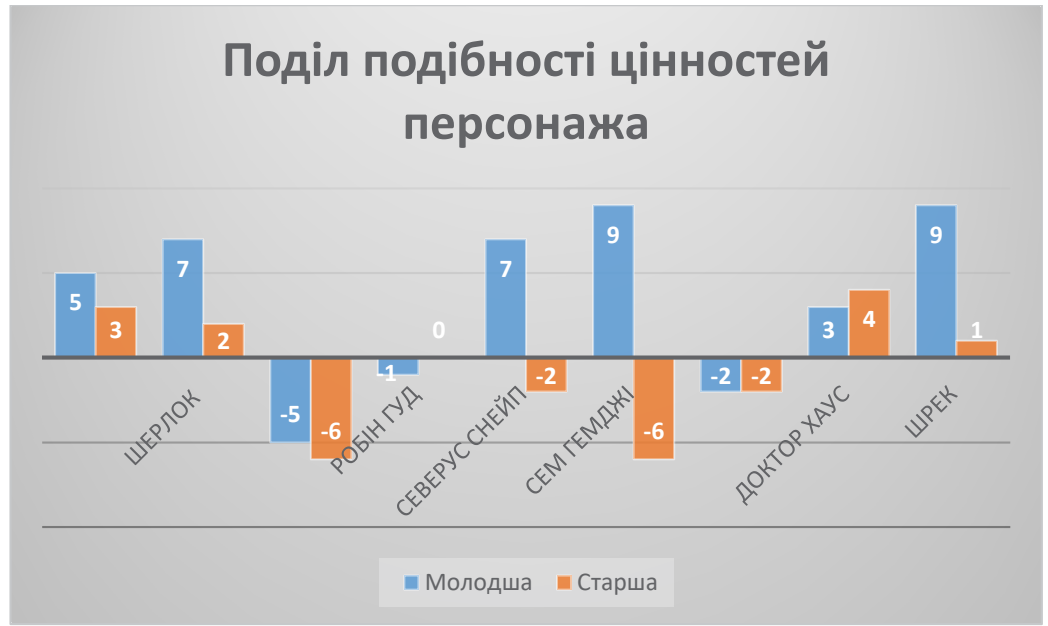

Рис. 1. Співпадіння (розбіжності) актуальних цінностей респондентів та цінностей персонажів

лодша аудиторія часто називала «дух», тобто сміливість, завзяття, рішучість, свободу, кмітливість. Тут загалом епітети були відмінними для кожного, щось загальне важко виокремити.

Майже ніхто не розчарувався у своїх героях дитинства окрім двох осіб, для яких прикладами для слідування були «піонер-герої» та «багато персонажів 3 різних мульт-серіалів» (різні по віку вибірки). Як пояснили самі досліджувані, у другому випадку це пов'язано з бажанням у дитинстві слідувати за модою та відсутність якихось конкретних рис у цих героях. У першому відповідь була коротка - «розчарувалася».

Наступне питання було таке: «з ким 3 цих персонажів ви б могли себе асоціювати, чиї дії, цінності, схожі на ваші?» Цікаві результати порівняння двох груп продемонстровані на графріку:

Список персонажів, які зустрічалися найчастіше:

- Герміона Грейнджер (фільми про Гаррі Поттера);

- Шерлок (серіал Шерлок);

- Залізна Людина (Месники);

- Робін Гуд;

- Северус Снейп (фільми про Гаррі Поттера);

- Сем Гемджі (кращий друг Фродо з фрільму Володар Перснів);

- Капітан Джек Горобець (Пірати Карибського моря);

- Доктор Хаус;

- Шрек.

Варто зауважити, колонка «не знаю цього персонажа» також була присутня, результати за нею просто не входили в загальне середнє по групам. За цим показником, як не дивно, більше персонажів не знала саме молодша аудиторія.

На графіку можна спостерігати, що найбільше балів асоціації набрав у дорослій аудиторії Доктор Хаус та Герміона Грейнджер (із фрільму про Гарpi Поттера). Молодша аудиторія більш за старшу схильна себе асоціювати 3 кимось 3 персонажів, при тому їх відповіді загалом схожі: найбільше поділяють вони цінності Сема Гемджі (найкращого друга Фродо з фрільму Володар Перснів), Северуса Снейпа, Шерлока (серіал) та Шрека. Цікавою $\epsilon$ різниця у поглядах на таких персонажів як Сем, Снейп та Шрек у двох групах вибірки. Останнього звичайно, розглядати можна сумнівно, через велику поширеність серед молоді мемів на дану тему, проте от перші два виявляються потрібними для детальнішого аналізу феноменом. Можна також припустити декілька гіпотез. Можливо, старші не розбирали та не повністю зрозуміли цих двох персонажів. Наразі дії Сема розуміються як відданість дружбі, якій він не боявся присвятити життя. Можливо, молодша аудиторія сприймає їх через емоційну, а не раціональну складову: подвиг сема так і подвиг Снейпа був заради дружби і любові. У контексті цих персонажів можна говорити про жертовність і альтруїзм, геройство i силу духу, поряд (включаючи Шрека) із не дуже гарним характером. Також треба помітити сам фракт того, що зараз Шрек є популярним у мемсередовищі, тобто молодь загалом поділяе ті цінності, що були висвітлені в мультику. Можливо, характер не є важливими для молодшої вибірки, принаймні не такими важливими як самі цінності, які можна побачити через дії, а не поведінку. Істині першопричини таких висновків можна спробувати розібрати через подальший розгляд результатів.

Досліджувані також мали відповісти на питання найкращої рольової моделі для їх дітей/ майбутніх дітей. Результати продемонстровані на діаграмі знизу:

Видно, що як доросла так і молода аудиторія найкращим прикладом для слідування дітей вважають Герміону та Робіна Гуда. При тому, все та ж велика різниця для Шрека, Доктора Хауса (з яким, певна річ, молодша аудиторія просто не достатньо знайома), Сема та Снейпа. Цікаво як розділилися погляди на Шерлока та Герміону. Як не дивно, молодші більш вважають Герміону гарним прикладом для слідування ніж старші (більшість 3 яких мала дітей шкільного віку). При тому, якщо зважати на те, що Герміона скоріше гарно вчилася та була кмітливою, а от Шерлок має дійсно геніальний розум, це порівняння стає цікавішим. Правда, для кращого аналізу треба зважати які саме критерії обирали групи для характеристики. Порівнюючи результати із попереднім графіком, можна сказати, що молоді все ж асоціюють себе із Шерлоком, проте не сильно хочуть, щоб майбутні діти були на нього схожими. Якщо брати загальні якості, по яким відо- 
Якості героїв, які найбільш часто зустрічаються у відповідях

Таблиця 1

\begin{tabular}{|c|c|c|}
\hline Група & Обов'язкові позитивні якості & Обов'язково відсутні негативні якості \\
\hline $\begin{array}{c}\text { Доросла } \\
(32-55 \text { років) }\end{array}$ & $\begin{array}{l}\text { Чесність, розум, людяність, доброта, } \\
\text { кмітливість, почуття гумору, шарм, самоіронія, } \\
\text { справедливість. }\end{array}$ & $\begin{array}{l}\text { Жадібність, жорстокість, брехливість, } \\
\text { підступність, егоїзм, заздрість, нечесність. }\end{array}$ \\
\hline $\begin{array}{c}\text { Молода } \\
\text { (19-25років) }\end{array}$ & $\begin{array}{l}\text { Розум, альтруїзм, доброта, старанність, } \\
\text { вірність, чесність, чуйність, милосердя, } \\
\text { порядність, відчуття справедливості. }\end{array}$ & $\begin{array}{l}\text { Егоїзм, лицемірство, зарозумілість, } \\
\text { тупість, брехливість, злоба, саркастичність, } \\
\text { безвідповідальність, заздрість. }\end{array}$ \\
\hline
\end{tabular}

мі дані персонажі, то молоді вважають за гарний приклад для слідування відданих, кмітливих та розумних персонажів, у той час як старша аудиторія - геніальних, кмітливих та героїчних. Ще б хотілось зауважити, що трохи соціопатів, зважаючи на характери Шерлока та Хауса. Очевидним за даними спостереженнями проситься висновок про те, що у молодої аудиторії герої більш соціальні та людяніші, у їх якостях існуе місце «іншої людини», у той час коли старша аудиторія спирається на саму цінність та суть, вдосконалення характеру.

Під кінець також варто проаналізувати якості, які виділили окремі групи, як ті, що обов'язково повинні бути в кожному позитивному герої та ті, що мають бути точно відсутні. Якщо виділяти найчастіші з них (табл. 1), можна отримати таку картину:

Як видно, результати відповідей з цього питання були схожими на попередні висновки. Для молодшої аудиторії найбільш позитивними якостями були розум та альтруїзм, якості пов'язані iз гарним ставленням до оточуючих, а негативні - ті, що пов'язані з їх зворотнім полюсом. До- росла аудиторія більш орієнтована на виховання власного характеру, більш не пов'язаного із соціумом, проте деякими вищими цінностями саморозвитку. Можна таким чином зробити висновок про індивідуалізм та орієнтуванні дорослих на своїй особистості, який прийшов із віком та прагненням до самовдосконалення, а молодших - на більшу людяність, орієнтування на соціум та проблеми навкруг, що також пов'язано певним чином із віковими особливостями:

Висновки. Як видно, доросла аудиторія не до кінця зрозуміла складних персонажів таких як Сем, Северус Снейп, Шрек і взагалі менш схильна асоціювати себе з будь-якими персонажами. Вона більш цінуе "поверхневі якості», а молодь на сьогодні цінять складність характеру і зважають на людину загалом, на її мотиви, а не на поведінку. У результатах не простежується тенденція, яку описують сучасні автори. Питання моралі залишаються актуальними як для молодих, так і для старших - в якості прикладу для наслідування ніхто не привів антигероя, також як і суб'єктивно сумнівні його якості. Так, образ

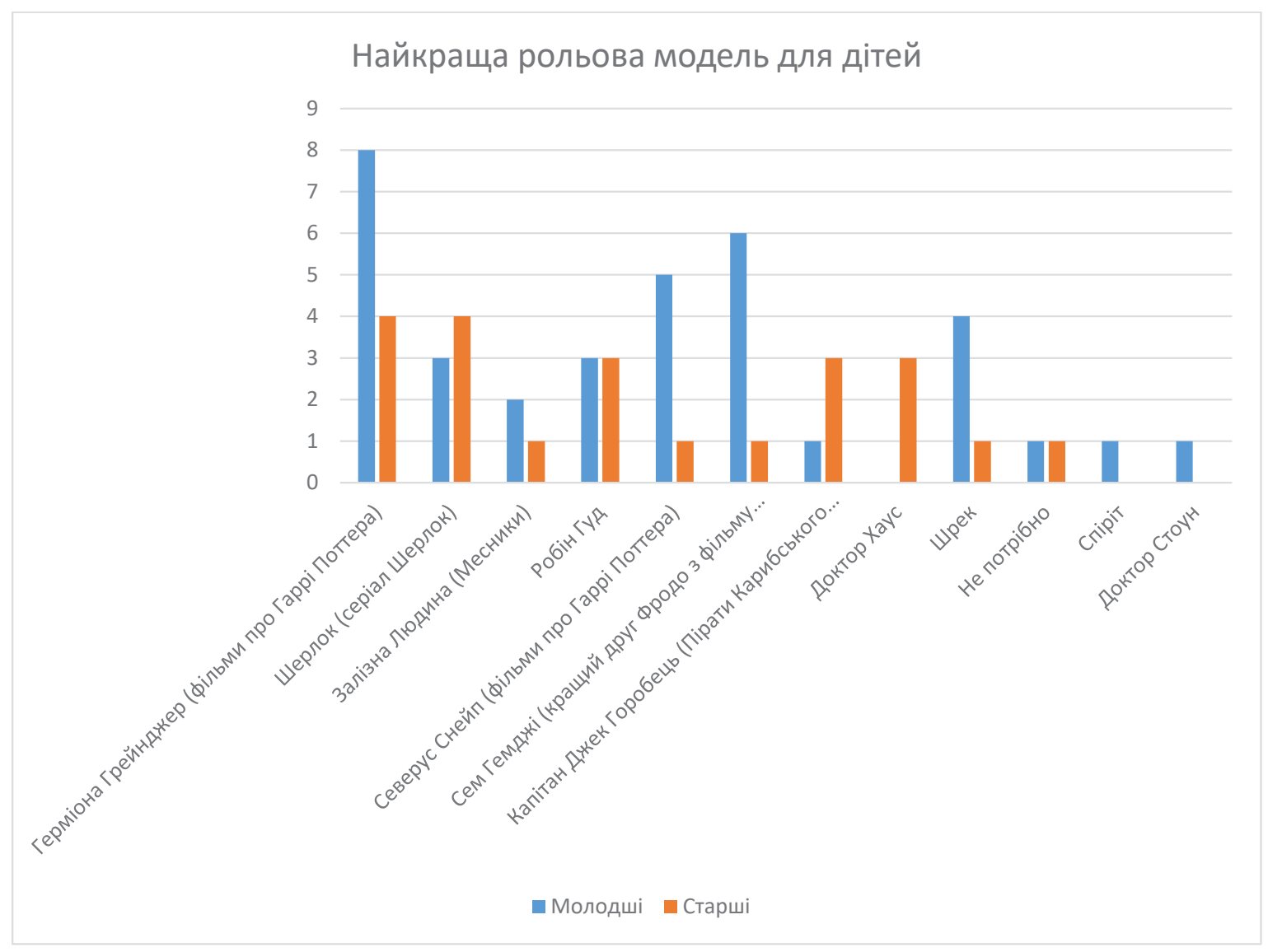

Рис. 2. Уявлення респондентів про найкращу рольову модель для дітей 
прикладу для слідування хоч і трохи змінюеться 3 різними поколіннями, але загальні його риси і спрямованість залишаються такими ж.

Різниця поколінь видна по якостям, які дві вибірки навели для героїв дитинства та героїв сьогодення (геройство для старшої вибірки та сила духу, неоднозначність для молодшої). Це можна пов'язати із зміною орієнтирів самого мас-медіа у тому, кого зараз розуміють героями. При тому гарне ставлення до антигероїв, таких як Моріарті, Джокер, Дедпул, Уолтер Уайт пов'язані не з суто позитивним до них ставленням, а скорше бажанням зрозуміти їх історії становлення особистостей та усесторонній погляд на будь-яке питання, бажання зрозуміти будь-кого.

Перспективи подальших досліджень. Тим не менш, дослідження містить багато неточностей та суб'єктивного бачення, тому є гарним полем для подальшого висунення гіпотез та виявлення дійсної причини різнищі у тому, як саме різні покоління вбачають рольові моделі для сучасного суспільства.

\section{Список літератури:}

1. Желобенко М. Современный сериал как инструмент коммуникационных технологий влияния («Игра престолов»). Литературная и медийная сферь: история, современность, перспективы. 2017. С. 93-97.

2. Ковалева Н.Б. Образ героя в представлениях подрастающего поколения в контексте проблемы становления их идентичности. АНИ: педагогика и психология. 2018. № 3(24). С. 317-321.

3. Немова О.А., Бурухина А.Ф. Мультипликационные фильмы как средство формирования семейных духовнонравственных ценностей. Вестник Московского университета. Социология и политология. 2014 . № 1. C. $152-173$.

4. Оконечникова Л.В., Садкина Т.М., Сумарокова Ю.И. Предпочитаемые младшими школьниками мультфильмы и экспертная оценка их родителями. Педагогическое образование в России. 2019. № 5. С. 97-102.

5. Собкин В.С., Калашникова Е.А. Представления об идеалах и антиидеалах у учащихся основной и старшей школы. ЧиО. 2017. № 2(51). С. 20-28. URL: https://cyberleninka.ru/article/n/predstavleniya-ob-idealah-iantiidealah-u-uchaschihsya-osnovnoy-i-starshey-shkoly (дата звернення: 13.05.2021).

6. Теряева О.А. Воспитание молодёжи: образы героев, псевдогероев и антигероев. Социальная педагогика. 2012. № 4. C. 107-120 URL: https://cyberleninka.ru/article/n/vospitanie-molodyozhi-obrazy-geroev-psevdogeroevi-antigeroev (дата звернення: 11.05.2021).

7. Чернобровкина С.В. Образ героя современных подростков. Весник Олского университета. Серия «Психология». 2013. № 2. С. 23-32. URL: https://cyberleninka.ru/article/n/obraz-geroya-sovremennyh-podrostkov (дата звернення: 18.05.2021).

8. Price-Mitchell, M. Tomorrow's Change Makers: Reclaiming the Power of Citizenship for a New Generation. Washington: Eagle Harbor Publishing. 2015. P. 290. URL: https://www.rootsofaction.com/role-model/

9. Vandenbos G.R. APA dictionary of psychology. 2006. Washington, DC : American Psychological Association.

\section{References:}

1. Zhelobenko M. (2017) Sovremennyy serial kak instrument kommunikatsionnykh tekhnologiy vliyaniya ("Igra prestolov»). Literaturnaya i mediynaya sfery: istoriya. sovremennost. Perspektivy, pp. 93-97.

2. Kovaleva N.B. (2018) Obraz geroya $\mathrm{v}$ predstavleniyakh podrastayushchego pokoleniya $\mathrm{v}$ kontekste problemy stanovleniya ikh identichnosti. ANI: pedagogika i psikhologiya, no. 3(24), pp. 317-321.

3. Nemova O.A., Burukhina A.F. (2014) Multiplikatsionnyye filmy kak sredstvo formirovaniya semeynykh dukhovnonravstvennykh tsennostey. Vestnik Moskovskogo universiteta. Sotsiologiya i politologiya, no. 1, pp. 152-173.

4. Okonechnikova L.V., Sadkina T.M., Sumarokova Yu.I. (2019) Predpochitayemyye mladshimi shkolnikami multfilmy i ekspertnaya otsenka ikh roditelyami. Pedagogicheskoye obrazovaniye v Rossii, no. 5, pp. 97-102.

5. Sobkin V.S., Kalashnikova E.A. (2017) Predstavleniya ob idealakh i antiidealakh u uchashchikhsya osnovnoy i starshey shkoly. ChiO, no. 2(51), pp. 20-28. URL: https://cyberleninka.ru/article/n/predstavleniya-ob-idealah-iantiidealah-u-uchaschihsya-osnovnoy-i-starshey-shkoly (accessed 13 May 2021).

6. Teryayeva O.A. (2012) Vospitaniye molodezhi: obrazy geroyev. psevdogeroyev i antigeroyev. Sotsialnaya pedagogika, no. 4, pp. 107-120 URL: https://cyberleninka.ru/article/n/vospitanie-molodyozhi-obrazy-geroevpsevdogeroev-i-antigeroev (accessed 11 May 2021).

7. Chernobrovkina S.V. (2013) Obraz geroya sovremennykh podrostkov. Vesnik Omskogo universiteta. Seriya "Psikhologiya", no. 2, pp. 23-32. URL: https://cyberleninka.ru/article/n/obraz-geroya-sovremennyh-podrostkov (accessed 18 May 2021).

8. Price-Mitchell. M. (2015) Tomorrow's Change Makers: Reclaiming the Power of Citizenship for a New Generation. Washington: Eagle Harbor Publishing, p. 290.

9. Vandenbos G.R. (2006) APA dictionary of psychology. Washington. DC: American Psychological Association. 